ORIGINAL ARTICLE

\title{
Evidence for interaction between the TCO and NMTC1 loci in familial non-medullary thyroid cancer
}

\author{
J D McKay, D Thompson, F Lesueur, K Stankov, A Pastore, C Watfah, S Strolz, G Riccabona, \\ R Moncayo, G Romeo, D E Goldgar
}

See end of article for authors' affiliations

a thors affilitions

Correspondence to: D E Goldgar, Unit of Genetic Epidemiology, International Agency for Research on Cancer, 150 Cours Albert Thomas, 69008 Lyon, France; goldgar@iarc.fr

Revised version received 21 January 2004 Accepted for publication 21 January 2004
Background: Familial non-medullary thyroid cancer (fNMTC) is a complex genetic disorder that is more aggressive than its sporadic counterpart. Thus far, three genetic loci have been implicated in susceptibility to $A$ NMTC by linkage analysis.

Methods: We used linkage analysis to test the significance of two of the known susceptibility loci for FNMTC, TCO on 19p13 and NMTC1 on 2q21 in 10 fNMTC families, nine of which present with cell oxyphilia, a rare histological phenotype associated with TCO. Furthermore, we used two-locus linkage analysis to examine the possibility that the TCO and NMTC1 loci interact to increase the risk of NMTC. Results: The 10 families provided evidence for linkage at both TCO and NMTC, with LOD scores of 1.56 and 2.85, respectively. Two-locus linkage analysis, using a multiplicative risk model for the development of NMTC, achieved a maximum LOD of 3.92 , with an LOD of 4.51 when assuming $70 \%$ of families were linked, indicating that the segregation in these families is consistent with an interaction model. Most of this evidence came from a large Tyrolean family that singularly achieved a two-locus LOD of 3.21.

Conclusions: These results provide further evidence that susceptibility genes for fNMTC exist at 19p13 and $2 q 21$, and furthermore, raise the possibility that in a subset of fNMTC pedigrees, these loci interact resulting in significantly increased risk of NMTC for patients that carry both susceptibility loci.
$\mathrm{N}$ on-medullary thyroid cancer (NMTC; OMIM\# 188550), including papillary thyroid cancer (PTC) and follicular thyroid cancer, is the most common form of thyroid cancer accounting for $80-90 \%$ of thyroid cancer patients. ${ }^{1}$ NMTC is associated with some of the highest familial risks among all cancer sites, with reported risks to first degree relatives of between 5- and 10-fold,,$^{2-4}$ and many multiplex pedigrees have been identified. Consequently, familial non-medullary thyroid cancer (fNMTC) has been recognised as a distinct clinical entity, characterised by a higher degree of aggressiveness and mortality compared to its sporadic counterpart. ${ }^{5-7}$ The mode of inheritance for fNMTC appears, on the whole, to be autosomal dominant although the majority of families are small (sibs/trios) and therefore a multigenic inheritance pattern is plausible. ${ }^{5689}$

Thus far, three susceptibility loci have been localised by genetic linkage analysis in FNMTC, with histopathological or additional clinical features playing a key role in reducing genetic heterogeneity. The TCO locus on $19 \mathrm{p} 13.2$ was identified in a large French family with a particular cellular phenotype, cell oxyphilia (or Hurthle cells), present in a number of the tumours in the family ${ }^{10}$ (OMIM\# 603386). The TCO linkage was subsequently confirmed in another pedigree with oxyphilia ${ }^{7}$ and in a family without oxyphilia. ${ }^{11}$ The PRNI locus was localised to chromosome 1q21 in a family with PTC and additional papillary renal neoplasia ${ }^{12}$ (OMIM\# 605642 ). Finally, we identified a susceptibility locus on 2q21, $N M T C 1$, that was suggested to account for a significant proportion of fNMTC, and appeared to be associated with another histopathological feature, the follicular variant of PTC (fvPTC) $)^{13}$ (OMIM\# 606240). Linkage to the PRNI and the NMTC1 loci has thus far not been replicated in independent family sets. Here, we tested the significance of the TCO and NMTCl loci in 10 families using linkage analysis and examined the possibility that these two loci interact to increase the risk of non-medullary thyroid cancer.

\section{METHODS}

Subsequent to the original publication of the TCO linkage on chromosome $19 \mathrm{pl} 3.2,{ }^{10}$ we have identified eight additional families in which at least one tumour was noted to have cell oxyphilia, including a large fNMTC pedigree from Austria (Tyrol) with six patients with NMTC and 12 patients with goitre (fig 1). On the basis of the presence of the oxyphilia phenotype, these families were excluded from our NMTCI mapping study. ${ }^{13}$ Additionally, we identified two families from our NMTC1 mapping study ${ }^{13}$ as being relevant here: one small family (201; three affected) identified as having "tall cells", a histological phenotype very similar to oxyphilia, ${ }^{10}$ and an informative Italian family (102) in which all tumours have not yet been examined in order to include/exclude the presence of oxyphilia or fvPTC. Histopathological diagnosis was confirmed in all cases. The families are summarised in table 1 . Blood samples and family history were obtained from family members after informed consent and DNA extracted (Puragene Kit, Gentra Systems) The protocol for this study was approved by the French committee for the Protection of Persons in Biomedical Research.

\section{Genotyping}

As nine of the 10 families were known to have at least one tumour with cell oxyphilia (or a similar feature), we genotyped these families for the TCO region on chromosome 19 as well as the NMTCl region on chromosome $2 \mathrm{q} 21$. Microsatellite markers genotyped in these families included on 2q21: D2S2224, D2S2271, D2S2215, D2S2160, D2S112, AFMa272zg9, D2S2256, D2S114, D2S368, D2S2196; and on 19p13: D19S1034, D19S901, D19S884, D19S391, D19S916, D19S586, D19S394 using standard PCR techniques with

Abbreviations: FNMTC, familial non-medullary thyroid cancer; fvPTC, follicular variant of PTC; LOH, loss of heterozygosity; PTC, papillary thyroid cancer 
Table 1 Summary of NMTC pedigrees used in this study

\begin{tabular}{lll}
\hline Family & $\begin{array}{l}\text { Number of } \\
\text { NMTC cases }\end{array}$ & $\begin{array}{l}\text { Number of additional } \\
\text { patients with goitre }\end{array}$ \\
\hline 103 & $6^{*} \dagger$ & 12 \\
128 & 3 & 0 \\
134 & 2 & 0 \\
188 & 4 & 0 \\
118 & 3 & 2 \\
39 & 2 & 0 \\
86 & $3^{*}$ & 0 \\
224 & 5 & 3 \\
201 & 3 & 0 \\
102 & $4 \dagger$ & 1 \\
\hline
\end{tabular}

*Includes one case with a Hurthle cell adenoma; tincludes one case with a follicular adenoma.

fluorescent primers and genotyped using a 377 Genetic Analyzer (Applied Biosystems).

\section{Statistical analysis}

Single-locus linkage analysis

A multipoint LOD score was calculated using the Vitesse analysis program ${ }^{14}$ restricted to three markers on chromosome 19p13 (D19S884-2.5 cM-D19S391-4.3 cM-D19S586) and three on chromosome 2q21 (D2S2215-3.45 cMD2S1260-3.69 cM-D2S112) due to the size of one of the families. Genetic distances were taken from Marshfield genetic maps ${ }^{15}$ or the genetic distance database ${ }^{16}$ and the marker order was confirmed using the human genomic sequence. ${ }^{17}$ Allele frequencies were those used in our previous linkage studies of these regions ${ }^{913}$ calculated from the larger data sets using one individual chosen from each family at random.

The genetic model chosen for each locus assumed a frequency of 0.01 for a dominantly inherited susceptibility allele at each locus and a 15-fold increased risk of NMTC (including follicular and Hurthle cell adenoma) above the assumed background rate of $0.2 \%$. In addition, we assumed that the susceptibility allele resulted in a three-fold increased risk of goitre independent of age or sex, with a prevalence in non-carriers of the allele of $5 \%$. Although this model is no doubt an oversimplification of the true underlying genetic basis, it captures the essential features of the effects of these two loci and satisfies constraints imposed by observed familial risk and disease prevalence. Under this model, each locus would be expected to produce a familial relative risk of 2.16 , which represents about $37 \%$ of the overall familial risk of 8.0 under a multiplicative model. Together these two loci are predicted to account for $58 \%$ of the total observed familial risk of NMTC under a multiplicative model, thus leaving room for one or more additional genes contributing to the familial aggregation.

\section{Two-locus linkage analysis}

Two-locus analysis was carried out by the TMLINK program. ${ }^{18}$ We assumed the joint presence of the TCO and NMTCl susceptibility loci described above, and further assumed that the loci acted multiplicatively in terms of cancer risk (that is, an individual carrying both susceptibility alleles would have a 225-fold increased risk) and additively in terms of the risk of goitre. We also performed analyses in which only patients with cancer/adenoma were considered as affected and looked at both multiplicative and additive models. In addition to the two locus analyses, we also calculated the LOD scores at each locus, assuming the other locus was in the model. Due to the size of the Tyrolean (103) family, to allow the calculation of a two-locus LOD score that used all available genetic data, the haplotypes of the family were recoded as a single informative locus with each haplotype assumed to be rare (fig $1 \mathrm{~A}, \mathrm{~B}$ ).

\section{RESULTS}

Evidence for linkage at the TCO and NMTC loci

For the 19p31.2 region, thought to contain the TCO locus, the overall maximum multipoint heterogeneity LOD score for the three markers in this region for the 10 families was 1.56 at marker D19S884, with an estimated $70 \%$ of the families linked to this region, providing further evidence of the presence of a fNMTC susceptibility gene at this locus. This was not surprising, as most of the families were selected for the presence of oxyphilia, which is a known phenotypic marker of the TCO locus. Somewhat more surprising, however, was our finding of linkage to the NMTCl locus in these pedigrees. The total LOD score using the three markers tested in this region was 2.85 at marker D2S2215, with no evidence of locus heterogeneity. This provides further strong evidence for the role of a locus in this region of $2 \mathrm{q} 21$ for fNMTC susceptibility. A major portion of the linkage signal at both 19p12 and 2q21 was due to a large Tyrolean pedigree (family 103). On 2q21, in this family (103) a patient who was affected with goitre (patient 103.27) is a recombinant. This patient was assumed to have received the "unaffected" haplotype because if they had received the "affected" haplotype this would be in contradiction with the critical 2 q21 region outlined in the NMTCl study..$^{13}$ Figure 1 shows the haplotypes for both regions in this family.

\section{Evidence for interaction between the TCO and NMTCI loci}

The finding of linkage to these two previously identified regions opens up the possibility that these two loci interact to produce a high risk of NMTC and other thyroid pathologies. In order to assess simultaneously the possibility of two loci interacting in these pedigrees, we performed two-locus linkage analysis in the 10 families using the genotype data from the TCO and NMTCl loci. Table 2 summarises the results of the two-locus linkage analyses performed. Under the model with both cancer and other thyroid pathology considered as affected, the two-locus analysis resulted in an overall LOD score of 3.92, with a value of 4.51 achieved under heterogeneity at $\alpha=0.70$, indicating that there is strong evidence in favour of a two-locus inheritance model. The large Tyrolean family again contributed significantly to the LOD score, with an individual two-locus LOD of 3.21 . Comparison of the individual LOD scores at each region showed a concordance of linkage results in nine out of the 10 families, with a Spearman rank correlation between the family LOD scores of 0.73 . This is also reflected in the fact that when considering cancer only, the multiplicative model seemed to fit better than the additive model, at least for the particular models examined.

The notion of two susceptibility loci interacting in these pedigrees is further supported by an examination of the segregating haplotypes of the families in which the sharing of the NMTC cases is consistent for linkage with both loci. In the large Tyrolean family (fig 1), we see that all six cases of NMTC share both the chromosome 19 and chromosome 2 haplotypes. For the potentially related phenotype of goitre, in 5/12 cases they shared both loci, in four shared NMTCl only but not TCO, and in the remaining three shared TCO but not NMTC1. Thus, all 12 cases of goitre carried at least one of the linked haplotypes. A similar haplotype segregation pattern is present among most of the other smaller linked families (fig 2 and data not shown). 


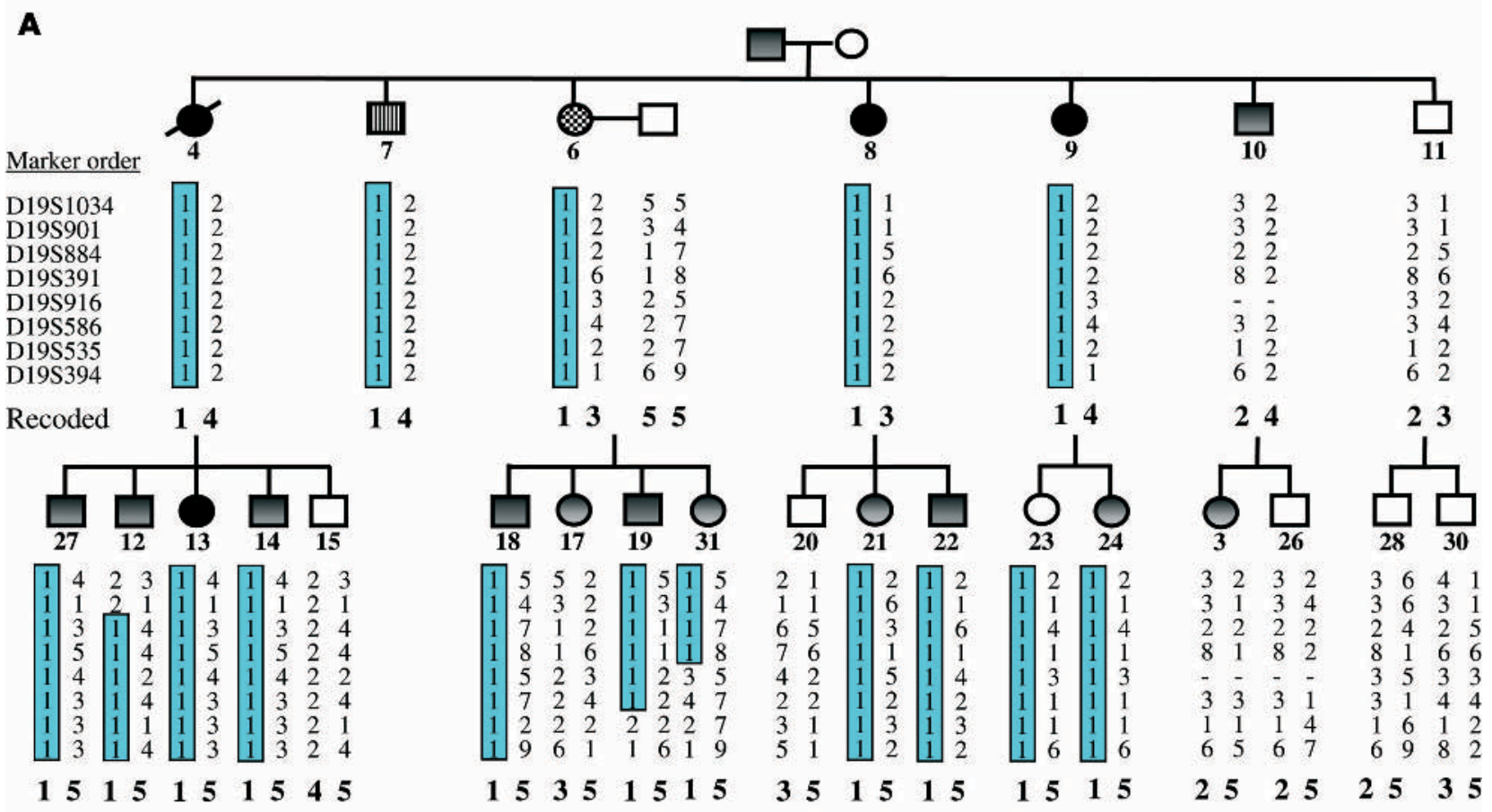

B

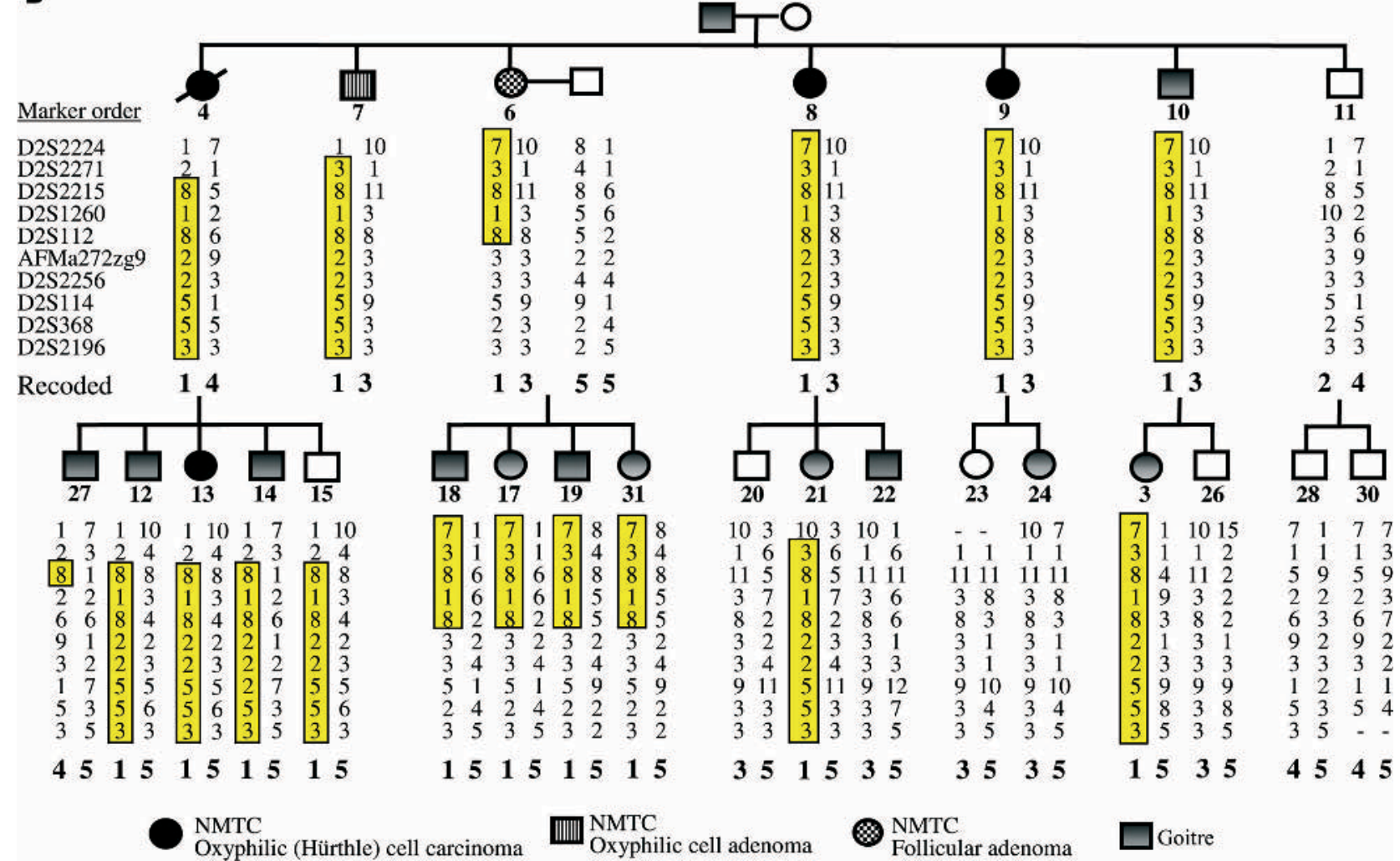

Figure 1 The haplotype of the large Tyrolean family (103) across 19p13 (A) and 2q21 (B). On 2q21, for recombinant patient 6 the position of the NTMC1 locus is further refined to the interval between D2S1260 and AFMa272zg9. Beneath each haplotype is shown the recoding used in the twolocus linkage analysis.

\section{DISCUSSION}

The linkage analysis performed in the 10 families presented here provides further evidence that $19 \mathrm{pl} 3$ and $2 \mathrm{q} 21$ harbour susceptibility genes for fNMTC. Among the 10 pedigrees presented here there is significant evidence for a twolocus inheritance pattern, indicating that among a subset of fNMTC pedigrees the TCO and NMTC1 loci may interact to result in increased risk of disease. However, the TCO locus appears not to be relevant to the majority of NNMTC $^{911}$ and neither the French family used to map the TCO locus nor the Tasmanian family used to map the NMTC1 locus presented with any evidence for linkage at the $2 \mathrm{q} 2 \mathrm{l}$ or 


\begin{tabular}{|c|c|c|c|c|c|c|c|c|c|}
\hline \multirow[b]{3}{*}{ Assume: } & \multirow{2}{*}{\multicolumn{3}{|c|}{$\begin{array}{l}\text { Cancer multiplicative } \\
\text { Goitre additive }\end{array}$}} & \multicolumn{6}{|c|}{ Cancer only } \\
\hline & & & & \multicolumn{3}{|c|}{ Multiplicative } & \multicolumn{3}{|l|}{ Additive } \\
\hline & 19 & 2 & & 19 & 2 & & 19 & 2 & \\
\hline & Linked & Linked & & Linked & Linked & & Linked & Linked & \\
\hline \multirow[t]{2}{*}{ Test: } & 2 & 19 & Both & 2 & 19 & Both & 2 & 19 & Both \\
\hline & Linked & Linked & linked & Linked & Linked & linked & Linked & Linked & linked \\
\hline 103 & 1.63 & 1.62 & 3.21 & 1.00 & 1.00 & 2.05 & 0.28 & 0.27 & 0.93 \\
\hline 128 & 0.48 & 0.22 & 0.70 & 0.48 & 0.21 & 0.69 & 0.24 & 0.06 & 0.36 \\
\hline 134 & -0.00 & -0.00 & -0.01 & -0.01 & -0.01 & -0.01 & -0.00 & -0.00 & -0.01 \\
\hline 188 & -0.52 & -0.55 & -1.07 & -0.52 & -0.55 & -1.06 & -0.28 & -0.29 & -0.45 \\
\hline 118 & 0.45 & 0.18 & 0.61 & 0.20 & 0.20 & 0.41 & 0.09 & 0.09 & 0.20 \\
\hline 39 & 0.17 & 0.17 & 0.34 & 0.18 & 0.18 & 0.35 & 0.09 & 0.09 & 0.20 \\
\hline 86 & 0.24 & -0.52 & -0.29 & 0.23 & -0.50 & -0.28 & 0.18 & -0.12 & 0.00 \\
\hline 224 & -0.71 & -0.28 & -0.96 & -0.80 & -0.34 & -1.14 & -0.30 & -0.17 & -0.39 \\
\hline 201 & 0.23 & 0.23 & 0.46 & 0.23 & 0.23 & 0.46 & 0.10 & 0.10 & 0.23 \\
\hline 102 & 0.37 & 0.60 & 0.94 & 0.47 & 0.47 & 0.95 & 0.17 & 0.17 & 0.45 \\
\hline Total & 2.33 & 1.66 & 3.92 & 1.47 & 0.90 & 2.42 & 0.56 & 0.20 & 1.51 \\
\hline HLOD & 2.39 & 1.78 & 4.51 & 1.59 & 1.06 & 3.17 & 0.5 & 0.21 & 1.51 \\
\hline$(\alpha)$ & $(0.85)$ & (0.7) & $(0.7)$ & $(0.85)$ & (0.7) & $(0.7)$ & $(1.0)$ & $(0.8)$ & $(1.0)$ \\
\hline
\end{tabular}

19 p13 loci, respectively. ${ }^{913}$ Therefore, it is unlikely that the TCO and NMTCl loci contribute to NMTC risk together among the majority of fNMTC pedigrees. Nevertheless, our results indicate that such an interaction may occur in a reasonably large subset of fNMTC and a two-locus mode of inheritance is consistent with the observations made of fNMTC $^{5689}$ and segregation analysis in other complex genetic forms of hereditary cancer fit a two-locus model. ${ }^{19} 2 \mathrm{q} 21$ has been noted as an area of interest in a genome wide search on a Canadian $M N G 1$ family, ${ }^{20}$ and it would be interesting to review these data in the context of the two-locus model outlined here, especially with respect to the three NMTC cases of the Canadian MNG1 family. ${ }^{20}$ Similarly $2 \mathrm{q} 21$ was implicated in a large family with Gardners syndrome ${ }^{21}$ in which NMTC has been found to be an associated tumour. ${ }^{22}$ Given the reported lack of biallelic inactivation of the APC gene in the thyroid carcinomas associated with familial adenomatous polyposis $^{23}$ and the reported cytogenetic alteration in the NMTCl region, ${ }^{21}$ it is possible that the NMTCl locus could
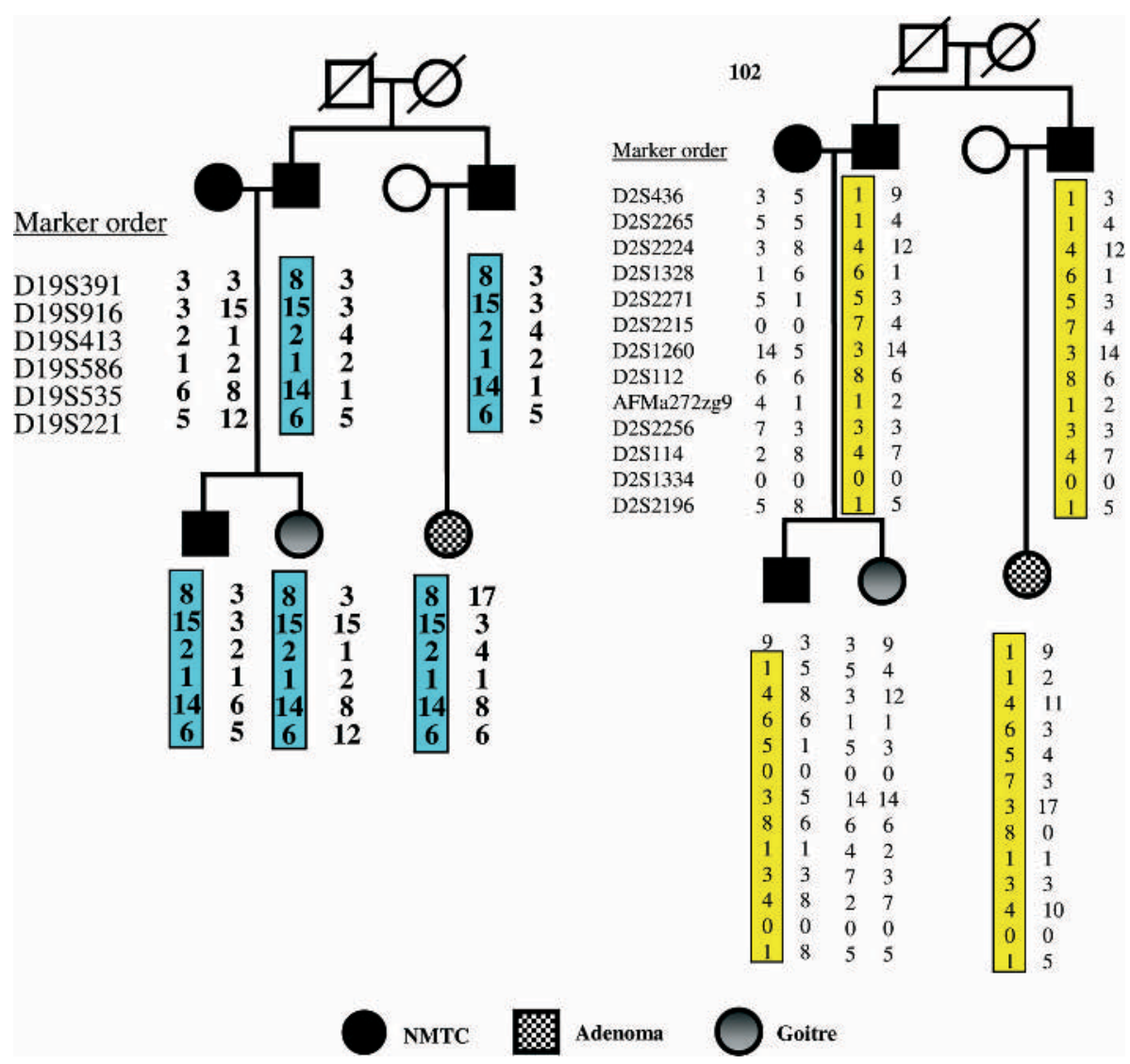

Figure 2 Family 102. This family of Italian background also presents with a haplotype that segregates on both the $2 q 21$ and 19p13 loci. The histopathology in this family was reported to be PTC but complete information was unavailable. 
be put forward as a modifier of NMTC susceptibility in this inherited syndrome. Examination of interaction models between the identified fNMTC loci and other genes that have been associated with NMTC risk, for example $R E T^{24}$ and more recently thyroglobulin ${ }^{25}$ in the wider familial NMTC without oxyphilia and sporadic NMTC may also be warranted.

Genetic heterogeneity has been reduced in fNMTC family sets by stratification on the presence of the histological variants of oxyphilia ${ }^{7}$ and fvPTC. ${ }^{13}$ Some families outlined here (for example families 118, 128, and 201; table 1) present with both the oxyphilia and fvPTC phenotypes. The evidence for linkage at both loci in this subset is therefore consistent with a stratification based on the presence of both the histological variants. Thorough histopathological data on all affected members of all pedigrees was not available for independent review to explore this observation further.

Loss of heterozygosity $(\mathrm{LOH})$ on chromosome 2 has been noted in oxyphilic NMTC tumours ${ }^{26}$ and at $2 \mathrm{q}_{22} 2^{27}$ suggesting further the NMTC1 locus may be implicated in the pathology associated with the TCO locus. In our own material from sporadic NMTC tumours, 35/71 (49\%) oxyphilic tumours and adenomas and NMTC with oxyphilic features exhibited LOH at $2 \mathrm{q} 21$ while only $38 \%$ of these tumours showed LOH at 19p13. Similarly in 20 follicular adenomas/carcinomas, $30 \%$ and $15 \%$ showed LOH at TCO and NMTC1, respectively (Stankov, unpublished data). However, in neither of the two sets of tumours was the number of tumours showing concordant $\mathrm{LOH}$ at both loci different from that expected under independence. Unfortunately, material was unavailable to test for allelic imbalance in the familial cases of this study.

These results provide further evidence for fNMTC susceptibility genes at 2q21 and 19p13.2. Furthermore, there is evidence that TCO and $N M T C 1$ may interact to increase risk in individuals that inherit both susceptibility genes. The identification of the NMTC susceptibility genes at both $2 q 21$ and 19p13.2 will allow the contribution of these two genes to the risk of developing NMTC to be fully characterised.

\section{ACKNOWLEDGEMENTS}

DT held a Postdoctoral Fellowship from the International Agency for Research on Cancer while working on the study reported in this paper.

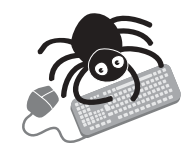

The URL for data in this report is as follows: Online Mendelian Inheritance in Man (OMIM), http:// www.ncbi.nlm.nih.gov/Omim/ (for NTMC, TCO, $P R N 1$, and NMTC1).

\section{Authors' affiliations \\ J D McKay, Menzies Center for Population Health Research, Hobart, Tasmania, Australia \\ D Thompson, D E Goldgar, International Agency for Research on Cancer, Lyon, France \\ F Lesueur, Strangeways Research Laboratory, Cambridge, UK \\ K Stankov, A Pastore, G Romeo, Genetica Medica, Bologna, Italy C Watfah, G Riccabona, R Moncayo, S Strolz, University of Innsbruck, Innsbruck, Austria}

This work was supported by grant QLG1-CT-2001-01646-"The RET Proto-Oncogene" from the EU, by an FIRB grant for PRIME "Progetto Integrato Malattie Ereditarie" from the Italian Ministry of Research, and by funds from the Almagem Foundation and the Carisbo Foundation (Bologna).

Conflict of interest: none declared.

\section{REFERENCES}

1 Schlumberger MJ. Papillary and follicular thyroid carcinoma. N Engl J Med 1998;338:297-306

2 Goldgar DE, Easton DF, Cannon-Albright LA, Skolnick MH. Systematic population-based assessment of cancer risk in first-degree relatives of cancer probands. J Natl Cancer Inst 1994:86:1600-8.

3 Hemminki K, Dong C. Familial relationships in thyroid cancer by histopathological type. Int J Cancer 2000;85:201-5.

4 Pal T, Vogl FD, Chappuis PO, Tsang R, Brierley J, Renard H, Sanders K, Kantemiroff T, Bagha S, Goldgar DE, Narod SA, Foulkes WD. Increased risk for nonmedullary thyroid cancer in the first degree relatives of prevalent cases of nonmedullary thyroid cancer: a hospital-based study. J Clin Endocrinol Metab 2001;86:5307-12.

5 Grossman RF, Tu SH, Duh QY, Siperstein AE, Novosolov F, Clark OH. Familial nonmedullary thyroid cancer. An emerging entity that warrants aggressive treatment. Arch Surg 1995;130:892-7.

6 Musholt TJ, Musholt PB, Petrich T, Oetting G, Knapp WH, Klempnauer J. Familial papillary thyroid carcinoma: genetics, criteria for diagnosis, clinical features, and surgical treatment. World J Surg 1995;24:1409-17.

7 Alsanea O, Clark OH. Familial thyroid cancer. Curr Opin Oncol 2001;13:44-51.

8 Burgess JR, Duffield A, Wilkinson SJ, Ware R, Greenaway TM, Percival J, Hoffman L. Two families with an autosomal dominant inheritance pattern for papillary carcinoma of the thyroid. J Clin Endocrinol Metab 1997;82:345-8.

9 Lesueur F, Stark M, Tocco T, Ayadi H, Delisle MJ, Goldgar DE, Schlumberger M, Romeo G, Canzian F. Genetic heterogeneity in familial nonmedullary thyroid carcinoma: exclusion of RET, MNGI and TCO in 56 families. J Clin Endocrinol Metab 1999;84:2157-62.

10 Canzian F, Amati P, Harach HR, Kraimps JL, Lesueur F, Barbier J, Levillain P, Romeo G, Bonneau D. A gene predisposing to familial thyroid tumors with cell oxyphilia maps to chromosome 19p13.2. Am J Hum Genet 1998;63:1743-8

11 Bevan S, Pal T, Greenberg CR, Green H, Wixey J, Bignell G, Narod SA, Foulkes WD, Stratton MR, Houlston RS. A comprehensive analysis of MNG1, TCO1, FPTC, PTEN, TSHR, and TRKA in familial nonmedullary thyroid cancer: confirmation of linkage to TCO1. J Clin Endocrinol Metab 2001;86:3701-4

12 Malchoff CD, Sarfarazi M, Tendler B, Forouhar F, Whalen G, Joshi V, Arnold A, Malchoff DM. Papillary thyroid carcinoma associated with papillary renal neoplasia: genetic linkage analysis of a distinct heritable tumor syndrome. J Clin Endocrinol Metab 2000;85:1758-64.

13 McKay JD, Lesueur F, Jonard L, Pastore A, Williamson J, Hoffman L, Burgess J, Duffield A, Papotti M, Stark M, Sobol H, Maes B, Murat A, Kaariainen H, Bertholon-Gregoire $M$, Zini $M$, Rossing MA, Toubert ME, Bonichon F, Cavarec M, Bernard AM, Boneu A, Leprat F, Haas O, Lasset C, Schlumberger M, Canzian F, Goldgar DE, Romeo G. Localization of a susceptibility gene for familial nonmedullary thyroid carcinoma to chromosome 2q21. Am J Hum Genet 2001:69:440-6.

14 O'Connell JR, Weeks DE. The VITESSE algorithm for rapid exact multilocus linkage analysis via genotype set-recoding and fuzzy inheritance. Nat Genet 1995; 11:402-8.

15 Broman KW, Murray JC, Sheffield VC, White RL, Weber JL. Comprehensive human genetic maps: individual and sex-specific variation in recombination. Am J Hum Genet 1998;63:861-9.

16 Collins A, Frezal J, Teague J, Morton NE. A metric map of humans: 23,500 loci in 850 bands. Proc Natl Acad Sci U S A 1996;93:14771-5.

17 Lander ES, Linton LM, Birren B, Nusbaum C, Zody MC, Baldwin J, Devon K, Dewar K, Doyle M, FitzHugh W, Funke R, Gage D, Harris K, Heaford A, Howland J, Kann L, Lehoczky J, LeVine R, McEwan P, McKernan K, Meldrim J, Mesirov JP, Miranda C, Morris W, Naylor J, Raymond C, Rosetti M, Santos R, Sheridan A, Sougnez C, Stange-Thomann N, Stojanovic N, Subramanian A, Wyman D, Rogers J, Sulston J, Ainscough R, Beck S, Bentley D, Burton J, Clee C, Carter N, Coulson A, Deadman R, Deloukas P, Dunham A, Dunham I, Durbin R, French L, Grafham D, Gregory S, Hubbard T, Humphray S, Hunt A, Jones M, Lloyd C, McMurray A, Matthews L, Mercer S, Milne S, Mullikin JC, Mungall A, Plumb R, Ross M, Shownkeen R, Sims S, Waterston RH, Wilson RK, Hillier LW, McPherson JD, Marra MA, Mardis ER, Fulton LA, Chinwalla AT, Pepin KH, Gish WR, Chissoe SL, Wendl MC, Delehaunty KD, Miner TL, Delehaunty A, Kramer JB, Cook LL, Fulton RS, Johnson DL, Minx PJ, Clifton SW, Hawkins T, Branscomb E, Predki P, Richardson P, Wenning S, Slezak T, Doggett N, Cheng JF, Olsen A, Lucas S, Elkin C, Uberbacher E, Frazier M, Gibbs RA, Muzny DM, Scherer SE, Bouck JB, Sodergren EJ, Worley KC, Rives CM, Gorrell JH, Metzker ML, Naylor SL, Kucherlapati RS, Nelson DL, Weinstock GM, Sakaki Y, Fujiyama A, Hattori M, Yada T, Toyoda A, Itoh T, Kawagoe C, Watanabe H, Totoki Y, Taylor T, Weissenbach J, Heilig R, Saurin W, Artiguenave F, Brottier P, Bruls T, Pelletier E, Robert C, Wincker P, Smith DR, Doucette-Stamm L, Rubenfield M, Weinstock K, Lee HM, Dubois J, Rosenthal A, Platzer M, Nyakatura G, Taudien S, Rump A, Yang H, Yu J, Wang J, Huang G, Gu J, Hood L, Rowen L, Madan A, Qin S, Davis RW, Federspiel NA, Abola AP, Proctor MJ, Myers RM, Schmutz J, Dickson M, Grimwood J, Cox DR, Olson MV, Kaul R, Raymond C, Shimizu N, Kawasaki K, Minoshima S, Evans GA, Athanasiou M, Schultz R, Roe BA, Chen F, Pan H, Ramser J, Lehrach H, Reinhardt R, McCombie WR, de la Bastide M, Dedhia N, Blocker H, Hornischer K, Nordsiek G, Agarwala R, Aravind L, Bailey JA, Bateman A, Batzoglou S, Birney E, Bork P, Brown DG, Burge CB, Cerutti L, Chen HC, Church D, Clamp M, Copley RR, Doerks T, Eddy SR, Eichler EE, Furey TS, Galagan J, Gilbert JG, Harmon C, Hayashizaki Y, Haussler D, Hermjakob H, Hokamp K, Jang W, Johnson LS, 
Jones TA, Kasif S, Kaspryzk A, Kennedy S, Kent WJ, Kitts P, Koonin EV, Korf I, Kulp D, Lancet D, Lowe TM, McLysaght A, Mikkelsen T, Moran JV, Mulder N, Pollara VJ, Ponting CP, Schuler G, Schultz J, Slater G, Smit AF, Stupka E, Szustakowski J, Thierry-Mieg D, Thierry-Mieg J, Wagner L, Wallis J,

Wheeler R, Williams A, Wolf YI, Wolfe KH, Yang SP, Yeh RF, Collins F, Guyer MS, Peterson J, Felsenfeld A, Wetterstrand KA, Patrinos A, Morgan MJ Szustakowki J, de Jong P, Catanese JJ, Osoegawa K, Shizuya H, Choi S Chen YJ; International Human Genome Sequencing Consortium. Initial sequencing and analysis of the human genome. Nature 2001;409:860-921.

18 Schork NJ, Boehnke M, Terwilliger JD, OH J. Two-trait-locus linkage analysis: a powerful strategy for mapping complex genetic traits. Am J Hum Genet 1993;53:1127-36.

19 Cui J, Staples MP, Hopper JL, English DR, McCredie MR, Giles GG. Segregation analyses of 1,476 population-based Australian families affected by prostate cancer. Am J Hum Genet 2001;68:1207-18.

20 Bignell GR, Canzian F, Shayeghi M, Stark M, Shugart YY, Biggs P, Mangion J Hamoudi R, Rosenblatt J, Buu P, Sun S, Stoffer SS, Goldgar DE, Romeo G, Houlston RS, Narod SA, Stratton MR, Foulkes WD. Familial nontoxic multinodular thyroid goiter locus maps to chromosome $14 \mathrm{q}$ but does not account for familial nonmedullary thyroid cancer. Am J Hum Genet 1997;61:1123-30.

21 Gardner EJ, Rogers SW, Woodward S. Numerical and structural chromosome aberrations in cultured lymphocytes and cutaneous fibroblasts of patients with multiple adenomas of the colorectum. Cancer 1982;49:1413-9.
22 Bell B, Mazzaferri EL. Familial adenomatous polyposis (Gardner's syndrome) and thyroid carcinoma: a case report and review of the literature. Digest Dis Sci 1993;38:185-90.

23 Cetta F, Curia MC, Montalto G, Gori M, Cama A, Battista P, Barbarisi A. Thyroid carcinoma usually occurs in patients with familial adenomatous polyposis in the absence of biallelic inactivation of the adenomatous polyposis coli gene. J Clin Endocrinol Metab 2001;86:427-32.

24 Lesueur F, Corbex M, McKay JD, Lima J, Soares P, Griseri $P$, Burgess J, Ceccherini I, Landolfi S, Papotti M, Amorim A, Goldgar DE, Romeo G. Specific haplotypes of the RET proto-oncogene are over-represented in patients with sporadic papillary thyroid carcinoma. J Med Genet 2002;39:260-5.

25 Matakidou A, Hamel N, Polpat S, Henderson K, Kantemiroff T, Harmer C, Clarke SE, Houlston RS, Foulkes WD. Risk of non-medullary thyroid cancer influenced by polymorphic variation in the thyroglobulin gene. Carcinogenesis 2004 (in press).

26 Segev DL, Saji M, Phillips GS, Westra WH, Takiyama Y, Piantadosi S, Smallridge RC, Nishiyama RH, Udelsman R, Zeiger MA. Polymerase chain reaction-based microsatellite polymorphism analysis of follicular and Hurthle cell neoplasms of the thyroid. J Clin Endocrinol Metab 1998;83:2036-42.

27 Tallini G, Hsueh A, Liu S, Garcia-Rostan G, Speicher MR, Ward DC. Frequent chromosomal DNA unbalance in thyroid oncocytic (Hurthle cell) neoplasms detected by comparative genomic hybridization. Lab Invest 1999;79:547-55. 